\title{
Evaluation of the Relationship Between the Severity of the Disease, the Neutrophil/ Lymphocyte Ratio and CRP in Children with Bronchiolitis
}

\section{Bronşiolit Tanısıyla İzlenen Çocuklarda Hastalığın Şiddeti ile Nötrofil/ Lenfosit Oranı ve CRP Arasındaki İlişkinin Değerlendirilmesi}

\author{
(D) Ömer Güneş, (1) Meltem Erol, (D Özlem Bostan Gayret, (D) Abdulrahman Özel, (D Övgü Büke
}

University of Health Sciences Turkey, İstanbul Bağcllar Training and Research Hospital, Clinic of Pediatrics, İstanbul, Turkey

\section{Abstract}

Objective: In this study, we aimed to evaluate the relationship among neutrophil-lymphocyte ratio (NLR), C-reactive protein (CRP) and disease severity in 0-2-year-old children diagnosed and hospitalized with bronchiolitis.

Method: This retrospective cross-sectional study includes 158 patients aged 0-2 years, who were hospitalized for bronchiolitis between 01.12.2018 and 04.01.2020 in University of Health Sciences Turkey, İstanbul Bağcılar Training and Research Hospital's Pediatrics Clinic. Patients' age, gender, laboratory results and disease severity scores were recorded. According to this, disease severity was categorized as mild, moderate and severe.

Results: No statistically significant difference was observed among the scores of disease severity, mean age of the groups and gender distribution $(p=0.061, p=0.392)$. However, a statistically significant difference was found between the disease severity score and the neutrophil/lymphocyte $(N / L)$ ratios $(p=0.007)$. The $N / L$ ratio of the "mild" group was seen as statistically significantly lower than that of the "moderate" and "severe" groups $(p=0.003, p=0.006)$. No statistically significant correlation was detected among the disease severity score, mean age of the moderate and severe groups $(r=0.081 p=0.311)$. A statistically significant difference was witnessed between the disease severity score and CRP values $(p=0.014)$. The CRP values of the group with mild disease were realized to be significantly lower than that of the group with moderate severity $(p=0.04)$.

Conclusion: An increase in the NLR along with CRP is associated with the clinical severity and is a beneficial parameter that can be used

\section{Öz}

Amaç: Çalışmamızda çocuk servisinde yatırılarak tedavi edilen bronşiolit tanısı alan 0-2 yaş arası çocuklarda nötrofil-lenfosit oranının (NLO) ve C-reaktif proteinin (CRP) hastalık şiddeti ile ilişkisinin değerlendirilmesi amaçlanmıştır.

Yöntem: Bu retrospektif kesitsel çalışmaya Sağlık Bilimleri Üniversitesi, İstanbul Bağcılar Eğitim ve Araştırma Hastanesi Çocuk Servisi'nde 01.12.2018-04.01.2020 tarihleri arasında bronşiolit nedeniyle yatırılarak takip edilen 0-2 yaş arası 158 hasta dahil edildi. Hastaların yaşı, cinsiyeti, laboratuvar sonuçları ve hastalık ciddiyet skorları kaydedildi. Bu skorlamaya göre hastalık ciddiyeti hafif, orta ve ağır olarak değerlendirildi.

Bulgular: Hastalık ciddiyet skoru ile grupların yaş ortalamaları arasında ve cinsiyet dağılımları arasında istatistiksel olarak anlamlı farklılık gözlenmemiştir ( $p=0,061, p=0,392)$. Hastalık ciddiyet skoru ile nötrofil/ lenfosit (N/L) oranı değerleri arasında istatistiksel olarak anlamlı farklılık gözlenmiştir ( $p=0,007)$. Hafif grubun $N / L$ oranı orta ve ağır gruplardan istatistiksel olarak anlamlı derecede düşük bulunmuş $(p=0,003, p=0,006)$, orta ve ağır grupların hastalık ciddiyet skoru ile yaş değerleri arasında istatistiksel olarak anlamlı korelasyon gözlenmemiştir $(r=0,081 p=0,311)$. Hastalık ciddiyet skoru ile CRP değerleri arasında istatistiksel olarak anlamlı farklıık gözlenmiştir $(p=0,014)$. Hastalık ciddiyeti hafif grubun CRP değerleri ciddiyeti orta olan gruptan anlamlı derecede düşük bulunmuştur $(p=0,04)$.

Sonuç: NLO'da artış CRP ile birlikte bronşiolit tanılı hastaların klinik ciddiyetiyle ilişkilidir ve çocuk servisinde yatan 0-2 yaş arası bronşiolit

Address for Correspondence: Özlem Bostan Gayret, University of Health Sciences Turkey, İstanbul Bağcılar Training and Research Hospital, Clinic of Pediatrics, İstanbul, Turkey

E-mail: drozlemgayret@gmail.com ORCID: orcid.org/0000-0003-4121-8009 Received: 29.06.2021 Accepted: 30.11.2021

Cite this article as: Güneş Ö, Erol M, Bostan Gayret Ö, Özel A, Büke Ö. Evaluation of the Relationship Between the Severity of the Disease, the Neutrophil/Lymphocyte Ratio and CRP in Children with Bronchiolitis. Bagcilar Med Bull 2021;6(4):438-443

${ }^{\odot}$ Copyright 2021 by the Health Sciences University Turkey, Bagcilar Training and Research Hospital Bagcilar Medical Bulletin published by Galenos Publishing House. 


\section{Abstract}

for evaluating the prognosis of 0-2-year-old hospitalized patients with bronchiolitis.

Keywords: Bronchiolitis, CRP, disease severity, neutrophil lymphocyte ratio

\section{Öz}

tanılı hastaların prognozunu değerlendirmek için kullanılabilecek faydalı bir parametredir.

Anahtar kelimeler: Bronşiolit, CRP, hastalık ciddiyeti, nötrofil lenfosit oranı

\section{Introduction}

Acute bronchiolitis mostly affects infants and is characterized by acute respiratory distress. Edema is an inflammatory process characterized by obstruction of bronchioles with mucus and cellular debris. Respiratory syncytial virus (RSV), being the most common, rhinoviruses, influenza virus, parainfluenza viruses, coronaviruses, metapneumovirus and rarely other respiratory tract viruses can also be the cause.

The most common cause of lower respiratory tract disease in infancy is acute bronchiolitis (1). Although it can be encountered in all seasons, it is mostly seen in winter, especially between October and May. It generally affects infants. It is the most common cause of hospitalization in this age group $(2,3)$. Airway inflammation, epithelial cells, macrophages, cytotoxic T-cells and eosinophils play a role in the pathogenesis of bronchiolitis (1). Moreover, it has been shown that neutrophil assembly is predominant in acute bronchiolitis (4). It has been reported that chemokines associated with high levels of neutrophils are increased in nasal and tracheal fluid samples taken from infants with RSV bronchiolitis (5). It has been shown previously that inflammation associated with IL-8 is correlated with the severity of the disease in patients with bronchiolitis (6). The diagnosis of bronchiolitis is mainly based on clinical findings, but acute phase reactants are also important in evaluating the clinical course of the disease. The most commonly used acute phase reactants in the clinic are blood leukocyte count (WBC), erythrocyte sedimentation rate (ESR), serum C-reactive protein (CRP) and serum procalcitonin $(5,6)$. Neutrophil/lymphocyte ratio (NLR), which is lately being used frequently, is a parameter used to evaluate inflammation and the clinical course of diseases.

In our study, it was planned to evaluate the relationship between NLR (which is an easily accessible and inexpensive parameter) and bronchiolitis severity score.

\section{Materials and Methods}

In this study, 158 patients in the 0 - 2 age group, who were hospitalized and treated with the diagnosis of bronchiolitis in University of Health Sciences Turkey, İstanbul Bağcllar Training and Research Hospital Pediatric Clinic between 1 December 2018 and 4 January 2020, were evaluated. Ethical approval for the study was obtained from University of Health Sciences Turkey, İstanbul Bağcllar Training and Research Hospital Ethics Committee (decree no: 2020.01.1.02.002, date 10.01.2020). Written informed consent was obtained in accordance with the Declaration of Helsinki.

Patients with severe immune deficiency, chronic neurological or cardiac disease and the children whose families did not approve to participate in the study were excluded from the study.

The diagnosis of bronchiolitis was made based on clinical findings. The patients had increased respiratory rate, chest retractions and wheezing. Prolonged expirium and sibilant rhonchi were detected. It was learned that the patients had upper respiratory tract infection symptoms such as runny nose, cough and mild fever 1-2 days before applying to the clinic. Radiologically, excess aeration in both lungs (parallelization of the ribs, flattening of the diaphragm, reduction in the mediastinum and heart area), peribronchial infiltrates and atelectasis were observed.

Grading of the disease: A scoring system taking into account the respiratory rate per minute, wheezing, retractions and general condition of the patient was used to evaluate the severity of the disease (7). According to this scoring system, patients were divided into three groups as mild, moderate and severe (Table 1).

Table 1. Acute bronchiolitis classification

\begin{tabular}{llll} 
& Mild & Moderate & Severe \\
\hline Apnea & Absent & Absent & + \\
Respiratory rate/min & $<50$ & $50-70$ & $>70$ \\
Heart rate/min & $<140$ & $140-160$ & $>160$ \\
Retractions & Mild & Moderate & Severe \\
$\mathrm{SaO}_{2}$ & $>93 \%$ & $86-92 \%$ & $<85 \%$ \\
$\mathrm{Cyanosis}_{\mathrm{Necessary} \mathrm{FiO}}$ for & Absent & Absent & + \\
$\mathrm{SaO}_{2}>93 \%$ & & $0.21-0.4$ & $>0.4$ \\
\hline
\end{tabular}


For complete blood count, 1-2 mL of blood was taken into an EDTA tube and studied in a Beckman Coulter (LH750) machine, and the NLR of the patients was calculated.

\section{Statistical Analysis}

In this study, statistical analyses were performed with the NCSS (Number Cruncher Statistical System) 2007 Statistical Software (Utah, USA) package program. In the evaluation of the data, the distribution of variables was examined with the Shapiro-Wilk normality test as well as descriptive statistical methods (mean, standard deviation, median, interquartile range), One-Way analysis of variance in intergroup comparisons of normally distributed variables, independent t-test in comparison of paired groups, KruskalWallis test in intergroup comparisons of non-normally distributed variables, Dunn's multiple comparison test in subgroup comparisons, chi-square test in comparisons of qualitative data, Pearson correlation test in comparison of variables with each other. The results were evaluated at the significance level of $\mathrm{p}<0.05$.

Mean, standard deviation, median, lower limit and upper limit summary criteria were given for continuous variables such as laboratory values. According to the distribution of these variables in the comparison of the groups; the t-test or One-Way analysis of variance was used in independent groups in normal distribution, the Mann-Whitney U test or Kruskal-Wallis test was used if not normally distributed. Number and percentage summary criteria were given for categorical variables such as gender and age. Chi-square test statistics were used to compare these in groups.

\section{Results}

Of the 158 patients included in the study, $96(60 \%)$ were male and no statistically significant difference was found between gender and disease severity $(\mathrm{p}=0.392)$ (Table 2). According to the disease severity scoring, 42 cases were mild with a mean age of $4.86 \pm 4.41$ months, 9 cases were moderate with a mean age of $7.36 \pm 6.31$ months, and 19 cases were severe with a mean age of $6 \pm 5.31$ months. No statistically significant difference was observed between the disease severity score and the mean age $(\mathrm{p}=0.061)$ (Table 2$)$.

The mean N/L ratio of the group with mild severity score was $0.69 \pm 0.52$, the median value was 0.54 (0.31-0.88), the mean N/L ratio of the group with moderate severity score was $1.66 \pm 1.99$, the median value was $0.84(0.44-2.34)$, and the mean N/L ratio of the group with severe severity score was $1.6 \pm 1.51$, and the median value was 1.10 (0.49-1.94). Statistically significant difference was observed between the groups ( $\mathrm{p}=0.007)$ (Table 3 ).

The mean CRP of the group with low disease severity score was found to be statistically significantly lower than that of the group with moderate disease severity $(\mathrm{p}=0.014)$, and no statistically significant difference was observed between the other groups ( $>>0.05)$ (Table 3$)$. The relationship between CRP and disease severity score is given in Graph 1.

The mean N/L ratio of the group with mild disease severity score was found to be statistically significantly lower than that of the groups with moderate and severe severity score $(\mathrm{p}=0.003, \mathrm{p}=0.006)$, and no statistically significant difference was observed between the groups with moderate and severe disease severity scores $(\mathrm{p}=0.003, \mathrm{p}=0.006=0.533$ ) (Table 4) (Graph 2).

Table 2. Relationship between patient's age and gender and disease severity score

\begin{tabular}{|c|c|c|c|c|c|c|c|c|}
\hline & & \multicolumn{6}{|c|}{ Disease severity score } & \multirow[t]{2}{*}{$\mathbf{p}$} \\
\hline & & \multicolumn{2}{|c|}{ Mild $n=42$} & \multicolumn{2}{|c|}{ Moderate $n=9$} & \multicolumn{2}{|c|}{ Severe $n=19$} & \\
\hline \multicolumn{2}{|c|}{ Age (months) } & \multicolumn{2}{|c|}{$4.86 \pm 4.41$} & \multicolumn{2}{|c|}{$7.36 \pm 6.31$} & \multicolumn{2}{|c|}{$6 \pm 5.31$} & 0.061 \\
\hline \multirow[t]{2}{*}{ Gender } & Male & 23 & $54.76 \%$ & 63 & $64.95 \%$ & 10 & $52.63 \%$ & \multirow{2}{*}{0.392} \\
\hline & Female & 19 & $45.24 \%$ & 34 & $35.05 \%$ & 9 & $47.37 \%$ & \\
\hline
\end{tabular}

Table 3. Relationship between CRP and N/L ratio and disease severity score

\begin{tabular}{|c|c|c|c|c|c|}
\hline & & \multicolumn{3}{|c|}{ Disease severity score } & \\
\hline & & Mild $n=42$ & Moderate $n=9$ & Severe $n=19$ & \\
\hline \multirow[t]{2}{*}{ CRP } & Mean \pm SD & $12.49 \pm 30.4$ & $23.5 \pm 46.38$ & $16.87 \pm 36.19$ & \multirow{2}{*}{0.014} \\
\hline & Median (IQR) & $4.35(1.22-12.65)$ & $11.04(3.07-22.85)$ & $4.33(1.84-18.18)$ & \\
\hline \multirow[t]{2}{*}{$\mathrm{N} / \mathrm{L}$ ratio } & Mean \pm SD & $0.69 \pm 0.52$ & $1.66 \pm 1.99$ & $1.6 \pm 1.51$ & \multirow{2}{*}{0.007} \\
\hline & Median (IQR) & $0.54(0.31-0.88)$ & $0.84(0.44-2.34)$ & $1.10(0.49-1.94)$ & \\
\hline
\end{tabular}

CRP: C-reactive protein, SD: Standard deviation, N/L: Neutrophil/lymphocyte, IQR: Interquartile range 
The mean CRP of the group with low disease severity score was found to be statistically significantly lower than that of the group with moderate disease severity $(\mathrm{p}=0.04)$, no statistically significant difference was observed between the other groups ( $>0.05$ ) (Table 4) (Graph 3).

While no statistically significant correlation was found between the disease severity score and age $(r=0.081$, $\mathrm{p}=0.311$ ), a statistically significant positive correlation was observed between the disease severity score and the mean $\mathrm{N} / \mathrm{L}$ ratio $(\mathrm{r}=0.206 \mathrm{p}=0.009)$ (Table 5$)$.

\section{Discussion}

The diagnosis of bronchiolitis is based on symptoms and physical examination findings, supported by complete blood count, serological tests and chest X-rays (8). Acute bronchiolitis is a limited inflammation of the tracheobronchial tree with edema and increased secretion in the mucosa of the large airways, and the use of antibiotics is usually unnecessary in treatment $(9,10)$. The clinical course may be more severe in cases with immunodeficiency, chronic lung disease, congenital

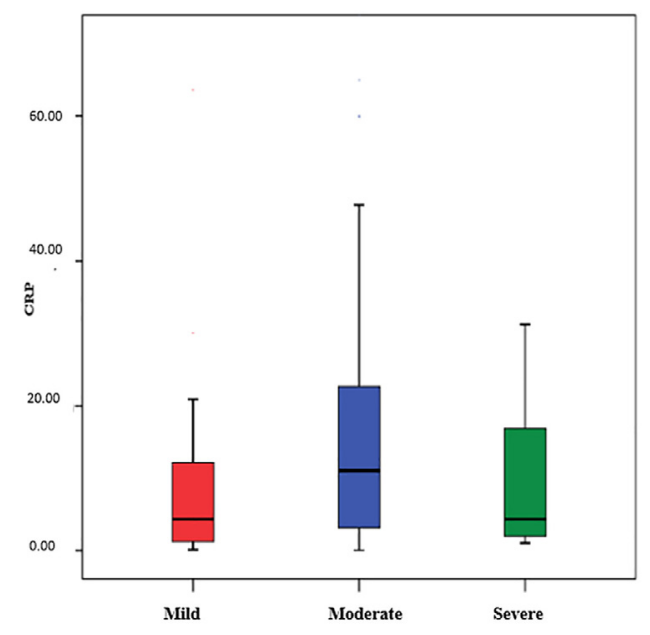

Graph 1. Relationship between CRP and disease severity score

CRP: C-reactive protein

Table 4. Comparison of CRP and N/L ratios of the groups

\begin{tabular}{lll} 
& CRP & N/L \\
& $\mathbf{p}$ & $\mathbf{p}$ \\
\hline Mild/moderate & $\mathbf{0 . 0 4}$ & $\mathbf{0 . 0 0 3}$ \\
Mild/severe & 0.342 & $\mathbf{0 . 0 0 6}$ \\
Moderate/severe & 0.240 & 0.533 \\
\hline
\end{tabular}

CRP: C-reactive protein, N/L: Neutrophil/lymphocyte heart disease or a history of premature birth. Laboratory tests (CRP values/CRP, mean platelet volume) were found to have no effect on predicting clinical severity $(11,12)$.

As a parameter, NLR is an inexpensive and easy to measure for determining the severity of diseases. NLR has been used in many studies and has recently been a frequently studied value in oncology and cardiovascular system patients (1315). A decrease in the number of lymphocytes, an increase in the number of neutrophils and a relative increase in NLR have been shown in previous studies in case of systemic inflammatory response (16-18).

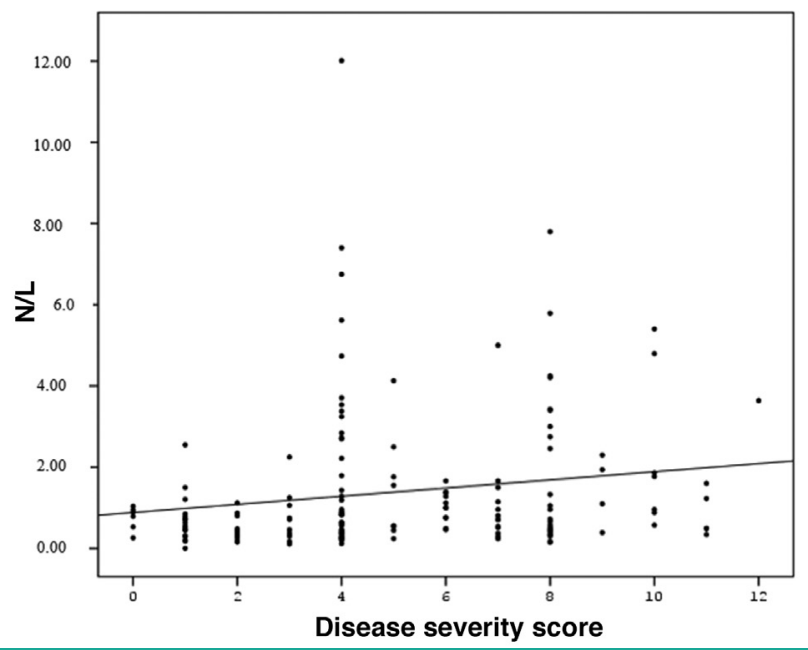

Graph 2. Relationship between N/L ratios and disease severity score

N/L: Neutrophil/lymphocyte

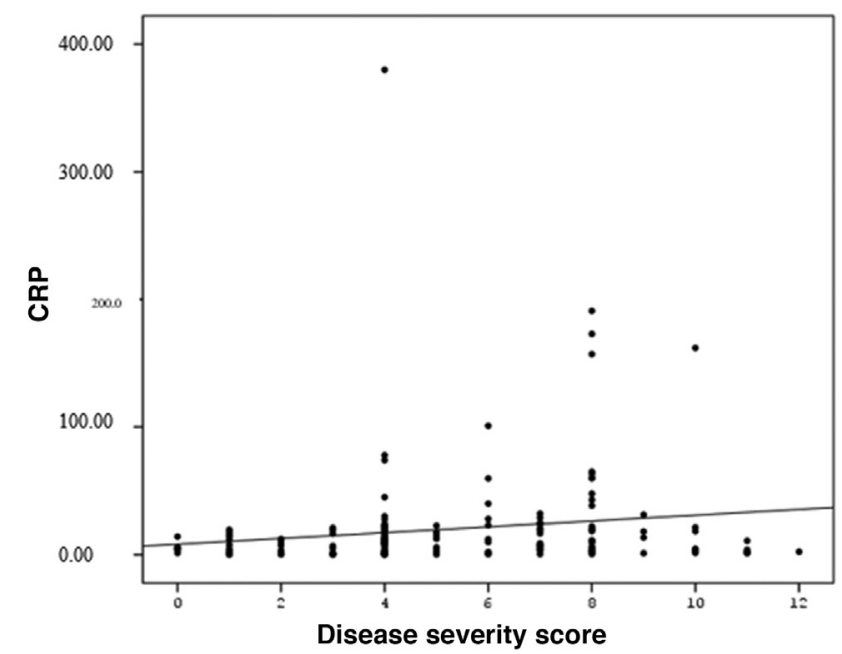

Graph 3. Relationship between CRP and disease severity score

CRP: C-reactive protein 
It is important to accurately determine the treatment plan of pediatric bronchiolitis patients. Auxiliary parameters are needed in the decision-making process. For this purpose, various scoring systems have been developed. Some blood tests are also used as a parameter of these scoring systems to help in diagnosis and treatment (19). Huang et al. (20) reported that NLR was associated with disease severity in patients with community-acquired pneumonia. Zahorec (21) reported that lymphocyte percentage decreased in sepsis and systemic inflammatory response in their study. This is explained by the increase in neutrophil ratio and decrease in lymphocyte ratio in inflammatory response states. Hwang et al. (22) reported that NLR could be used as an inexpensive and easy prognostic marker in septic and critically ill patients. In our study, it was observed that as the severity of bronchiolitis increased, neutrophils increased, and lymphocytes decreased, which was reflected as an increase in NLR. At the same time, in our study, it was observed that the CRP value increased in proportion to the severity of the disease, and the increase in both CRP and NLR in proportion to the severity of the disease is an indicator of the increase in these parameters with inflammation, which is compatible with the previous literature.

In a study by de Jager et al. (23), it was found that there was a correlation between high NLR and increased mortality in chronic diseases. In another study by de Jager et al. (24), high NLR was found to be more valuable than leukocyte and neutrophil values in predicting bacteremia in the emergency department. In a study by Yoon et al. (25) on tuberculosis and bacterial pneumonia patients, NLR was found to be significantly higher in bacterial pneumonia patients.

In our study, the increase in NLRs in accordance with the severity of the disease in pediatric patients with bronchiolitis supports previous studies. As the severity of the infection increases, the neutrophil ratio increases and the lymphocyte ratio decreases. Bronchiolitis can have a

\begin{tabular}{|c|c|c|}
\hline & & Disease severity score \\
\hline \multirow[t]{2}{*}{ Age (months) } & $\mathbf{r}$ & 0.081 \\
\hline & p & 0.311 \\
\hline \multirow[t]{2}{*}{ CRP } & $\mathbf{r}$ & 0.159 \\
\hline & p & 0.046 \\
\hline \multirow[t]{2}{*}{$N / L$} & $\mathbf{r}$ & 0.206 \\
\hline & p & 0.009 \\
\hline
\end{tabular}

CRP: C-reactive protein, N/L: Neutrophil/lymphocyte serious course especially in young children and may result in pediatric intensive care unit admittance. Therefore, we think that NLR, which is an inexpensive and easy parameter, can be meaningful and important in terms of showing the course of the disease.

In a study by Çelik Güzel et al. (26) it was found that while NLR increased as the severity of the disease increased in children with acute bronchiolitis similar to our study, CRP did not increase in line with the severity of the disease. In our study, CRP also increased in line with the severity of the disease.

Bircan et al. (27) reported that the severity of pneumonia was related to the level of CRP, and that there was a statistically significant difference between CRP, WBC and ESR values in inpatients and outpatients. In another study conducted in our country, the severity of pneumonia was found to be associated with high CRP and WBC levels, while there was no difference in ESR and fibrinogen. In addition, a statistically significant relationship was found between mortality and high CRP (28).

\section{Study Limitations}

The limitations of our study are that it was a retrospective study and NLR was not compared with a healthy control group of same age and gender. The positive side of our study is that disease severity scoring was used to evaluate the patients.

\section{Conclusion}

NLR is a systemic inflammatory response marker that has been used increasingly in recent years. The fact that it is cheap, easily accessible and useful as clinically demonstrated in previous studies increase its value.

Increased neutrophil lymphocyte ratio and CRP are associated with the clinical severity of bronchiolitis, and can be used to determine the severity of the disease in pediatric patients aged 0-2 years with a diagnosis of bronchiolitis.

\section{Ethics}

Ethics Committee Approval: Ethical approval for the study was obtained from University of Health Sciences Turkey, İstanbul Bağcılar Training and Research Hospital Ethics Committee (decree no: 2020.01.1.02.002, date 10.01.2020).

Informed Consent: Written informed consent was obtained in accordance with the Declaration of Helsinki.

Peer-review: Externally and internally peer-reviewed. 


\section{Authorship Contributions}

Concept: Ö.G., M.E., Design: Ö.G., M.E., Data Collection or Processing: Ö.G., A.Ö., Ö.B., Analysis or Interpretation: Ö.G., M.E., Ö.B.G., Drafting Manuscript: M.E., Ö.B.G., Ö.B., Critical Revision of Manuscript: Ö.B.G., A.Ö., Final Approval and Accountability: M.E., Ö.B.G., A.Ö., Technical or Material Support: Ö.B., M.E., Supervision: M.E., Ö.B.G.

Conflict of Interest: No conflict of interest was declared by the authors.

Financial Disclosure: The authors declared that this study received no financial support.

\section{References}

1. Florin TA, Plint AC, Zorc JJ. Viral bronchiolitis. Lancet 2017;389(10065):211-224.

2. Schroeder A, Mansbach JM. Recent evidence on the management of the bronchiolitis. Curr Opin Pediatr 2014;26(3):328-333.

3. GBD 2015 LRI Collaborators. Estimates of the global, regional, andnational morbidity, mortality, and aetiologies of lower respiratory tract infections in 195 countries: a systematic analysis for the Global Burden of Disease Study 2015. Lancet Infect Dis 2017;17(11):1133-1161.

4. Li YT, Liang Y, Ling YS, Duan MQ, Pan L, Chen ZG. The spectrum of viral pathogens in children with severe acute lower respiratory trac tinfection: A 3-year prospective study in the pediatric intensive care unit. J Med Virol 2019;91(9):1633-1642.

5. KligJE, Shah NB. Office pediatrics: current issues in lower respiratory infections in children. Curr Opin Pediatr 2005;17(1):111-118.

6. Hopstaken RM, Muris JW, Knottnerus JA, Kester AD, Rinkens PE, Dinant GJ. Contributions of symptoms, signs, erythrocyte sedimentation rate, and C-reactive protein to a diagnosis of pneumonia in acute lower respiratory tract infection. Br J Gen Pract 2003;53(490):358-364.

7. Toraks Derneği. Çocukluk çağında toplumdan kazanılmış pnömoni ve akut bronşiyolit tanı ve tedavi rehberi. 2002. Erişim adresi: http://www.toraks.org

8. Ralston SL, Lieberthal AS, Meissner HC, Alverson BK, Baley JE, Gadomski AM, et al. Clinical practice guideline: the diagnosis, management, and prevention of bronchiolitis. Pediatrics 2014;134(5):e1474-e1502.

9. Meissner HC. Viral bronchiolitis in children. N Engl J Med 2016;374(1):62-72.

10. Costa S, Rocha R, Tavares M, Bonito-Vítor A, Guedes-Vaz L. C Reactive protein and disease severity in bronchiolitis. Rev Port Pneumol 2009;15(1):55-65.

11. Ergül AB, Altuner Torun Y, Uytun S, Aslaner H, Paç Kısaaslan A, Şerbetçi MC. Reduction in mean platelet volume in children with acute bronchiolitis. Turk Pediatri Ars 2016;51(1):40-45.

12. Janahi I, Abdulkayoum A, Almeshwesh F, Alkuwari M, Hammadi A, Alameri M. Viral aetiology of bronchiolitis in hospitalised children in Qatar. BMC Infect Dis 2017;17(1):139.

13. Liu CL, Lee JJ, Liu TP, Chang YC, Hsu YC, Cheng SP. Blood neutrophilto-lymphocyte ratio correlates with tumor size in patients with differentiated thyroid cancer. J Surg Oncol 2013;107(5):493-497.

14. Xiao Q, Zhang B, Deng X, Wu J, Wang H, Wang Y, et al. The Preoperative Neutrophil-To-Lymphocyte Ratio Is a Novel Immune Parameter for the Prognosis of Esophageal Basaloid Squamous Cell Carcinoma. PLoS One 2016;11(12):e0168299.

15. Kim BJ, Cho SH, Cho KI, Kim HS, Heo JH, Cha TJ. The combined impact of neutrophil-to-lymphocyte ratio and type 2 diabetic mellitus on significant coronary artery disease and carotid artery atherosclerosis. J Cardiovasc Ultrasound 2016;24(2):115-122.

16. Fang Q, Tong YW, Wang G, Zhang N, Chen WG, Li YF, et al. Neutrophil-to-lymphocyte ratio, obesity, and breast cancer risk in Chinese population. Medicine (Baltimore) 2018;97(30):e11692.

17. Ding Y, Zhang S, Qiao J. Prognostic value of neutrophil-tolymphocyteratioin melanoma:EvidencefromaPRISMA-compliant meta-analysis. Medicine (Baltimore) 2018;97(30):e11446.

18. Wang J, Xiao W, Chen W, Hu Y. Prognostic significance of preoperative neutrophil-to-lymphocyte ratio and platelet-tolymphocyteratio in patients with glioma. Excli J 2018;17:505-512.

19. Hatherill M, Tibby SM, Sykes K, Turner C, Murdoch IA. Diagnostic markers of infection: comparison of procalcitonin with $\mathrm{C}$ reactive protein and leucocyte count. Arch Dis Child 1999;81(5):417-421.

20. Huang Y, Liu A, Liang L, Jiang J, Luo H, Deng W, et al. Diagnostic value of blood parameters for community-acquired pneumonia. Int Immunopharmacol 2018;64:10-15.

21. Zahorec R. Ratio of neutrophil to lymphocyte counts--rapid and simple parameter of systemic inflammation and stress in critically ill. Bratisl Lek Listy 2001;102(1):5-14.

22. Hwang SY, Shin TG, Jo IJ, Jeon K, Suh GY, Lee TR, et al. Neutrophilto-lymphocyte ratio as a prognostic marker in critically-ill septic patients. Am J Emerg Med 2017;35(2):234-239.

23. de Jager CP, Wever PC, Gemen EF, Kusters R, van GageldonkLafeber AB, van der Poll T, et al. The neutrophil-lymphocyte count ratio in patients with community-acquired pneumonia. PLoS One 2012;7(10):e46561.

24. de Jager CP, van Wijk PT, Mathoera RB, de Jongh-Leuvenink J, van der Poll T, Wever PC. Lymphocytopenia and neutrophil-lymphocyte count ratio predict bacteremia better than conventional infection markers in an emergency care unit. Crit Care 2010;14(5):R192.

25. Yoon NB, Son C, Um SJ. Role of the neutrophil-lymphocyte count ratio in the differential diagnosis between pulmonary tuberculosis and bacterial community-acquired pneumonia. Ann Lab Med 2013;33(2):105-110.

26. Çelik Güzel E, Fidan Ç, Güzel S, Paketçi C. Can neutrophil/ lymphocyte ratio be used as a new biomarker in the evaluation of disease activity in children with bronchiolitis? Namık Kemal Med J 2019;7(1):13-18.

27. Bircan A, Kaya Ö, Gökırmak M, Öztürk Ö, Şahin Ü, Akkaya A. C-reactive protein, leukocyte count and ESR in the assessment of severity of community-acquired pneumonia. Tüberküloz ve Toraks Dergisi 2006;54(1):22-29.

28. Kolsuz M, Metintaş M, Uçgun İ. The relations between levels of acute phase reactants and severity of community acquired pneumonia. Tüberküloz ve Toraks Dergisi 2002;50(4):431-437. 